\title{
REFLECTIONS ON A LEGAL EDUCATION ABROAD: METACOGNITIVE OPPORTUNITIES, KNOWLEDGE AND COGNITIVE COMPLEXITY, AND CULTURAL GLOBALIZATION
}

\author{
COMMENT \\ Mark L. Shope* \\ There is no type of legal study that will strengthen the muscles of the \\ mind like the comparative study of two great legal systems. ${ }^{1}$
}

Our self-awareness, beliefs, values, and behavior reflect a cultural context. ${ }^{2}$ We are not born with culture-specific awareness. ${ }^{3}$ Because we live in an era of intense economic, technological, cultural, political, and environmental globalization, we must frequently interact with those who have beliefs, values, and behaviors different from our own. These encounters may, and often do, conflict with our own worldview, the normative framework that defines an individual's knowledge and perspective. ${ }^{4}$ How do we cope with this potential mismatch? We must first increase our awareness of our inner experiences, which may be challenging if awareness of the inner self has not been an important component of our upbringing. ${ }^{5}$ A closed mind, or a mind that has not engaged in selfreflection, may interfere with adopting appropriate methods of moving forward in a multicultural situation. "Individuals learn to value the culturespecific values and beliefs they are born into before they are capable of examining the impact of these culture-specific values and beliefs on the formation of their own understanding of self." 7 In other words, we reflect on how culture-specific values and beliefs impact our understanding of self only after we have learned, largely by our upbringing, to value (or be stifled by) those culture-specific values and beliefs.

\footnotetext{
*The author is a graduate of the IU McKinney School of Law and the National Taiwan University College of Law. He is an associate in the corporate group at the law firm of Faegre Baker Daniels LLP. The views and opinions expressed here are his own and in no way represent the views, positions, or opinions — expressed or implied — of any other person.

${ }^{1}$ Arthur T. Vanderbilt, Law School Study After the War, 20 N.Y.U. L. REv. 146, 160 (1944-1945).

${ }^{2}$ Heesoon Jun, Social Justice, Multicultural Counseling, and Practice: Beyond a CONVENTIONAL APPROACH 62 (2010).

${ }^{3}$ Id. at 60 .

${ }^{4}$ Allison AbBe et al., Cross-Cultural Competence in ARmy Leaders: A Conceptual and EMPIRICAL FOUNDATION 15 (2007).

${ }^{5}$ Jun, supra note 2, at 60 .

${ }^{6} I d$.

${ }^{7}$ Id. (citing SUSAN BLACKMORE, CONSCIOUSNESS: AN INTRODUCTION (2004)).
} 
An education that incorporates a foreign cultural perspective allows us to recognize those culture-specific values that form our understanding of the self because we are forced to step outside, albeit temporarily, of our cultural frame of reference. ${ }^{8}$ " $[\mathrm{T}] \mathrm{o}$ change norms, it is necessary to introduce new group members who have different norms in a social environment. To change attitudes, including behavioral intentions, it is necessary to provide new information and social situations in which people behave inconsistently with their attitudes and are reinforced for doing so."9 Learning in different cultures does just that. It allows us to face these inconsistencies head on. When we adapt to this new educational environment, we are rewarded for behaving inconsistently with our previous behavioral norms because these behavior norms are "normal" in the new educational environment. For example, we may be rewarded by a professor who perceives an answer that uses a more collectivist approach (if such a culture values the collective as opposed to an individualistic approach). We may be rewarded for knowing when to use language that incorporates humility and respect because this shows that we are valuing the histories, traditions, and value systems imbedded in such language. Because of this we grow. Preconceptions, beliefs, concepts, and judgments about ourselves, others, and the universe break down, and our illusion of separateness dissolves.

The staff of the Indiana International \& Comparative Law Review asked me to reflect on my legal educational experiences abroad for their 2014 Symposium titled Moving to Opportunity: Examining the Risks and Rewards of Economic Migration. ${ }^{10}$ As such, my goal in this brief reflection

\footnotetext{
${ }^{8}$ An education that incorporates a foreign cultural perspective, for purposes of this reflection, refers to an education abroad. Indeed, there are domestic opportunities that incorporate a foreign cultural perspective, but the current article will not address these opportunities.

${ }^{9}$ Harry Triandis, The Analysis of SubJective Culture 343 (1972).

${ }^{10}$ In 2006, I was given the opportunity to study in Taiwan through a scholarship from the Ministry of Education of Taiwan. This scholarship included studying Mandarin for one year at the National Taiwan Normal University Mandarin Training Center and two years in a master's degree of my choice. I chose to study in a LL.M. program at the National Taiwan University College of Law ("NTU”). The curriculum included Mandarin studies, private international law, WTO Law (NTU hosted the Asian Center for WTO \& International Health Law and Policy; Justice and Professor Chang-fa Lo was a WTO panelist for a trade dispute between EC and Brazil (Brazil - Retreaded Tyres; DS332) (2006)), Taiwan Legal System (I was a teaching assistant for this course and assisted the professor with instructional responsibilities), comparative law, IP law, international arbitration, and Law Review. I was an associate editor for two journals: the Contemporary Asia Arbitration Journal and the Asian Journal of WTO \& International Health Law and Policy. I lived in the university dormitories with two or sometimes three other classmates in the College of Law. I participated in study groups, language exchanges, field trips, had an advisor and was for all purposes a normal student at the law school. I was not part of an exchange program. In 2010, I was given the opportunity to study in China at Remin University School of Law through the IU McKinney School of Law China Summer Program. I was given the opportunity to complete an internship at the Centre for Civil and Political Rights in Switzerland. I also spent three weeks at a
} 
is to cogitate about such experiences. I will start with a discussion of the metacognitive aspects of my experiences. I will then discuss cognitive complexity issues, cultural globalization issues, and briefly conclude. Much of what I have to say will be from the perspective of studying at a foreign university, but many of the ideas are relevant to summer, semester, and academic year abroad programs, gap year programs, academic exchanges, and other such programs.

\section{METACOGNITIVE OPPORTUNITIES}

Metacognition refers to higher order thinking which involves monitoring one's own cognitive processes. ${ }^{11}$ In other words, we are thinking about and being critical of our own thinking. This includes knowledge of cognition in general and the regulation of one's own cognition. ${ }^{12}$ One of the key features of a legal, or any, education abroad is the fact that the "inbound" students are outside of their own culture, which allows for unexpected situations and experiences. When thrust into these situations, there is a tendency to search for help to interpret this new state of affairs. The sense of our own cognition is heightened, and we begin to allocate and reorganize cognitive resources in order to deal with these situations and experiences. ${ }^{13}$ The ability to allocate cognitive resources such that we can adequately deal with the discord in our present, dominant cognitive mode(s) is central to intelligence. ${ }^{14}$

A person who is particularly self-directed and self-aware has a high knowledge about oneself as a learner and can adjust to the changing situational demands of each learning task. Educational psychologist Gregory Schraw has developed a three-part framework for metacognitive control: planning, monitoring, and evaluating. ${ }^{15}$ With regard to the planning feature, students are asked to reflect on the following questions: What is the nature of the task; what is my goal; what kind of information and strategies do I need; how much time and resources will I need? With regard to the monitoring feature, students are asked to reflect on the following questions: Do I have a clear understanding of what I am doing; does the task make sense; am I reaching my goals; do I need to make changes? With regard to the evaluating feature, students are asked to reflect on the following questions: Have I reached my goal; what worked; what didn't work; would

social sciences translation workshop at Fudan University through a program administered by UCLA. I illustrate these experiences to provide context to my reflection.

${ }^{11}$ JenNifER A. Livingston, MetACognition: An Overview 3 (2003).

12 Gregory Schraw, Promoting General Metacognitive Awareness, 26 Instructional ScIENCE 113, 113 (1998).

${ }^{13}$ I've also seen cognitive discord in those who resist dealing with these unexpected experiences.

${ }^{14}$ LIVINGSTON, supra note 11.

${ }^{15}$ Schraw, supra note 12, at 121. 
I do things differently next time? ${ }^{16}$

I found that in studying abroad one will begin to ask similar questions of one's own learning, and use Schraw's compendium of questions to monitor one's own cognitive processes. For example, in many learning situations my classmates and I would ask: What skills do we need to utilize; do we simply need knowledge of specifics; do we need to be able to apply the acquired knowledge; based on our interactions with each other, was it apparent that we are reaching our goals; how do we know if we are reaching our goals? ${ }^{17}$

I found that the experience of learning abroad makes us turn inward to take a critical look at how we learn, simply because from a cultural standpoint our existing categories and scripts may not be effective in the new situation. Indeed, "[c]ulture is 'the interactive aggregate of common characteristics that influence a human group's response to its environment." "18 Before I went abroad, I was part of a human group with common characteristics that were different than the culture in which I chose to study. The legal ideologies that were a facet of my conscience did not fit nicely with the legal ideologies of the culture in which I was studying. There are those who believe that "every culture has a unique legal order, with distinctive legal institutions, practices, and ideology that evolve in the context of its overall social order." ${ }^{19}$ Thus, there are details of a legal system, or distinctive practices and ideology, that evolve in such a way that our existing cognitive structures may have a difficult time processing this new information. I observed that those who were studying abroad at the law school struggled with the new cognitive environment, but usually emerged with a sharper sense of their own cognitive processes because they were forced to reflect upon and reorganize these cognitive processes. Those legal ideologies that were once confusing and a mismatch with our own legal ideologies were now more understandable and could coexist with our existing cognitive frameworks.

Learning abroad exposes us to information and social situations, which are inconsistent with our current cognitive scripts. In order to deal with these differing learning situations, we must turn inward and reflect

${ }^{16}$ Id.

${ }^{17}$ Not surprisingly, these questions are similar to Bloom's taxonomy of learning objectives. See Benjamin S. Bloom, Taxonomy of Educational Objectives Book 1: Cognitive Domain (2d ed. 1984).

18 Nora V. Demleitner, Combating Legal Ethnocentrism: Comparative Law Sets Boundaries, 31 ARIz. ST. L.J. 737, 739-40 (1999) (quoting Michael King, Comparing Legal Cultures in the Quest for Law's Identity, in COMPARING LEGAL CULTURES 119, 132 (David Nelken ed., 1997)).

${ }^{19}$ Janet E. Ainsworth, Categories and Culture: On the "Rectification of Names" in Comparative Law, 82 CoRnell L. REV. 19, 28 (1996). On the other hand, there are those who believe that the "legal order occupies the same structural niche in every culture, so that the superstructural details of legal systems may vary dramatically from society to society, but the fundamental structural functions of all legal orders are universally identical.” Id. 
upon our own cognitive capacities. We begin to monitor our learning more. We evaluate our learning more. Because of this we become better overall learners. ${ }^{20}$

\section{KNOWLEDGE AND COGNITIVE COMPLEXITY}

When we study outside an educational institution imbedded in our own culture, we are confronted with unexpected situations and experiences. ${ }^{21}$ These unexpected situations may not fit into existing knowledge structures that help us make sense of how our everyday life events unfold. ${ }^{22}$ Knowledge and assumptions from our own culture may be a mismatch for the new environment, and a closed mind may interfere with adopting more appropriate alternatives. ${ }^{23}$ In unexpected situations we are challenged to behave differently, reconsider what is expected of us, as well as what to expect from others. The degree to which we can apply multiple perspectives when perceiving and evaluating stimuli reflects our level of cognitive complexity. ${ }^{24}$ Cognitive complexity "[r]epresents the degree to which a potentially multidimensional cognitive space is differentiated and integrated. A cognitively complex person would employ differentiation and integration as part of his or her information processing." 25 A fertile setting to hone these skills of differentiation and integration is the classroom in a law school abroad where cultural paradoxes are seemingly everywhere-the professor and his or her delivery is unfamiliar, the curriculum is unfamiliar, the language may be unfamiliar, teaching and learning methods are unfamiliar, the expectations placed on the student are unfamiliar-but eventually our minds make sense of it. "An increasingly complex understanding of culture allows one to recognize and make sense of cultural paradoxes-apparent contradictions between cultural values or practices that emerge as one becomes more familiar with a foreign culture." ${ }^{26}$ In other words, the cognitive process involved in making sense of cultural paradoxes is similar to that involved in making sense of our curricular

\footnotetext{
${ }^{20}$ Margaret Y. K. Woo, Reflections on International Legal Education and Exchanges, 51 J. LEGAL EDUC. 449, 452 (2001) ("By understanding legal skills, culture, and values, and by knowing the places of overlap as well as the sites of divergence, we can better prepare our students to work more collegially and successfully with our foreign counterparts. To be successful, then, international exchanges require us to delve deeper into understanding our own motivations, needs, and creativity, as well as those of our counterparts from other cultures.”).

${ }^{21}$ ABBE ET AL., supra note 4, at 15.

22 Mary Kosut, Encyclopedia OF Gender in Media 39 (2012).

${ }^{23}$ ABBE ET AL., supra note 4, at 17.

${ }^{24}$ Duane P. Truex \& Jungwoo Lee, Cognitive Complexity and Methodical Training: ENHANCING OR SUPPRESSING CREATIVITY 1 (2000).

25 Truex \& LeE, supra note 24, at 1-2, quoting Siegried Streufert \& Robert W. Swezey, COMPLEXITY, MANAGERS, AND ORGANIZATIONS 18 (1986).

${ }^{26}$ ABBE ET AL., supra note 4, at 15.
} 
experiences abroad. Because of this we become more cognitively complex individuals.

We must actively develop our awareness of our inner experiences to be effective lawyers. ${ }^{27}$ Study abroad is one setting where we can sharpen our awareness of the self and cultivate the cognitive processes characteristic of a person with an open mind. When we are called upon to apply and actively utilize multiple perspectives when perceiving, evaluating, and acting upon stimuli, we are polishing, or heightening, our cognitive complexity. When our cognitive complexity is heightened, we can tackle the unknown with greater dexterity, which makes us more successful as lawyers. We have heightened emotional and cognitive empathy and we have the ability to adjust our cognitive frames of reference in response to different cues in our practice. We can think and feel as others do, and at the same time we develop a heightened sense of identity. When we are tasked to differentiate between ourselves in our culture and ourselves in another culture, we become keenly aware of our identity because of our race, class, religion, gender, ethnicity, ideology, nationality, sexual orientation, culture, history, medical condition, or profession. At the same time, we realize that we are not bound by these identities, or any other reified constructs and objects. We call into question these binary modes of ethnocentric experience, and replace them with less ethnocentric modes of thought.

\section{CULTURAL GLOBALIZATION}

There are many aspects to globalization-environmental, political, economic prosperity, health, and culture-just to name a few. Cultural globalization refers to "the process of cultural flows" across the world, and how "contact between people and their cultures - their ideas, their values, their ways of life-have been growing and deepening." ${ }^{28}$ Law is a system of "political arrangements, social relations, interpersonal interactional practices, economic processes, cultural categorizations, normative beliefs, psychological habits, philosophical perspectives, and ideological values."29 Thus, law is a feature of culture. ${ }^{30}$ Since law is a feature of culture, it is involved in the process of interaction and integration among cultures. ${ }^{31}$ This

${ }^{27} I d$.

${ }^{28}$ B. Kumaravadivelu, Cultural Globalization and Language Education 37, 38 (2007) (citing United Nations Development Programme, Human Development Report 199918 (1999)).

${ }^{29}$ Ainsworth, supra note 19, at 28.

${ }^{30}$ Demleitner, supra note 18, at 739; contra id. at 741 ("Law is 'a particular type of social norms supported by a set of values/ideas under the legitimate authority/power of a certain social organization.' In that respect, law is different from culture and requires analysis based on these narrower terms.”).

31 Cultural globalization can be divided into three models: cultural homogenization, cultural heterogenization, and cultural glocalization. KuMARAVADIVELU, supra note 28, at 38. Cultural 
interaction changes the contours of the law and creates new rules, norms, and legal institutions. The law is changing because of this two-way process in which cultures in contact shape and reshape each other. ${ }^{32}$ Commonalities and similarities should be recognized; diversity and difference should be embraced and managed, not abolished. ${ }^{33}$ A legal education abroad can be one way to give lawyers the tools to recognize commonalities and similarities as well as differences in legal cultures. ${ }^{34}$ When studying abroad, we are thrust into a situation where we need to identify similarities with our own legal system to establish a frame of reference with which to proceed. Subtle contours of these similarities become apparent, and we begin to appreciate the connections between legal cultures. The diversity also becomes apparent, but hopefully we are able to make sense of these differences and incorporate them into our being. ${ }^{35}$ Legal professionals will more and more be called upon to rectify the influences of the law of different jurisdictions on our own legal system. We will also be called upon to interpret our own law for those in other jurisdictions. A legal education abroad will give us the tools to accomplish this.

\section{CONCLUSION}

As our self-awareness, beliefs, values, and behavior develop through this era of economic, technological, cultural, political, and environmental globalization, so must our thoughts about delivery of legal services, which begins with a proper legal education. Inclusion of culture-specific values and legal norms from other legal systems are becoming more mainstream in legal thought. ${ }^{36}$ This inclusion of culture-specific values and legal norms from other legal systems has important consequences for legal education

homogenization holds that cultural globalization is the progressive outward spreading of one dominant culture (currently American culture). Id. Cultural heterogenization posits that cultural globalization has actually led to a rise in preservation of local cultures and religion, mainly as a reaction to the threat of the dominant culture. Id. Cultural glocalization refers to simultaneous homogeneous and heterogeneous cultural development "where the global is localized and the local is globalized." Id.

32 Kumaravadivelu, supra note 28, at 44.

33 Demleitner, supra note 18, at 746.

${ }^{34}$ Michael P. Scharf, Internationalizing the Study of Law, 20 PENN ST. INT’L L. REV. 29, 30 (2001) (“A second reason for internationalizing the curriculum is to better prepare students to practice law in any field, since inter-national law issues are becoming more and more common throughout the practice of law.”).

${ }^{35}$ Demleitner, supra note 35, at 739. ("Where do law and legal order begin, and where does culture end? A broad interpretation of culture renders it difficult, if not impossible, to delineate the two clearly. Culture is "the interactive aggregate of common characteristics that influence a human group's response to its environment.”).

${ }^{36}$ Indeed, "a significant proportion of the Justices of the Supreme Court have indicated, in opinions and extrajudicial statements, their intention to introduce a wider range of comparative material into Supreme Court practice.” H. Patrick Glenn, Comparative Law and Legal Practice: On Removing the Borders, 75 Tul. L. REV. 977, 988 (2001). 
and legal practices that are becoming increasingly transnational in nature. This movement "propagates legal ideas outside their place of origin, where they become subject to local, inevitably comparative, evaluation, whether they are received or not." 37 Whether we are consciously receiving and integrating comparative legal thought, it is reaching our subconscious and forming those culture-specific values that form our understanding of the self. ${ }^{38}$

Since a legal education "prepares individuals to be law services providers," 39 the mechanism for gaining a legal education must include international components. ${ }^{40}$ When one studies abroad, one must turn inward to take a critical look at how he or she learns, simply because from a cultural standpoint his or her existing categories and scripts may not be effective in the new situation. The student is honing his or her metacognitive skills by monitoring one's own cognitive processes. An Association of American Colleges and Universities report calls for higher education to help "students become intentional learners who can adapt to new environments, integrate knowledge from different sources, and continue learning throughout their lives." ${ }^{41}$ The report states further that "[i]ntentional learners are integrative thinkers who can see connections in seemingly disparate information and draw on a wide range of knowledge to make decisions." ${ }^{42}$ Learning in different cultures allows us to do just that. When we are learning abroad, we are asked to face inconsistencies head on, make connections with seemingly disparate information, and widen our range of knowledge to make informed decisions. We are becoming informed learners through exposure to "the interrelations within and among global and cross-cultural communities." 43 This prepares us to be effective legal service providers.

The underlying praxis of a cross-cultural legal education undermines attachment to dualistic legal classifications and sabotages the awareness of oneself and one's legal system as standing apart from the world, of self versus other, or "us" versus "them." A cross-cultural legal education provides resources for overcoming such entanglement in ideology, and helps us to see the world more clearly.

\footnotetext{
${ }^{37}$ Glenn, supra note 36, at 984.

${ }^{38}$ Id. at 988 .

39 AMERICAN BAR Association, TASK ForCE ON the FutURE OF LEgAL EdUCATION, REPORT AND RECOMMENDATIONS 5 (January 2014).

${ }^{40}$ See generally Luz Estella Nagle, Maximizing Legal Education: The International Component, 29 STETSON L. REV. 1091 (2000).

41 Association of American Colleges and Universities, Greater Expectations, A NeW VISION FOR LEARNING AS A NATION GOES TO COLLEGE XI (2002).

${ }^{42} I d$. at 21.

${ }^{43} I d$. at 23.
} 